\title{
Mapping Internet Financial Reporting: A Bibliometric Review
}

\section{Mathew Kevin Bosi, Nelson Lajuni, Mohd Noor Azli bin Ali Khan}

To Link this Article: http://dx.doi.org/10.6007/IJARAFMS/v11-i3/11526 DOI:10.6007/IJARAFMS /v11-i3/11526

Received: 16 July 2021, Revised: 21 August 2021, Accepted: 10 September 2021

Published Online: 29 September 2021

In-Text Citation: (Bosi et al., 2021)

To Cite this Article: Bosi, M. K., Lajuni, N., \& Khan, M. N. A. bin A. (2021). Mapping Internet Financial Reporting: A Bibliometric Review. International Journal of Academic Research in Accounting Finance and Management Sciences, 11(3), 813-827.

\section{Copyright: @ 2021 The Author(s)}

Published by Human Resource Management Academic Research Society (www.hrmars.com)

This article is published under the Creative Commons Attribution (CC BY 4.0) license. Anyone may reproduce, distribute, translate and create derivative works of this article (for both commercial and non-commercial purposes), subject to full attribution to the original publication and authors. The full terms of this license may be seen at: http://creativecommons.org/licences/by/4.0/legalcode

\section{Vol. 11, No. 3, 2021, Pg. 813 - 827}




\title{
Mapping Internet Financial Reporting: A Bibliometric Review
}

\author{
Mathew Kevin Bosi ${ }^{1}$, Nelson Lajuni², Mohd Noor Azli bin Ali \\ $\mathrm{Khan}^{3}$ \\ 1,2Faculty of Business, Economics and Accountancy, Universiti Malaysia Sabah (UMS),
} 88400 Kota Kinabalu, Sabah, Malaysia, ${ }^{3}$ Azman Hashim International Business School, Block

T08, Universiti Teknologi Malaysia (UTM), 81310, Johor Bahru, Johor, Malaysia

Corresponding Author Email: nelsonl@ums.edu.my

\begin{abstract}
Internet financial reporting (IFR) has become the center of discussion among practitioners and researchers as the global economy is undergoing a rapid digital transformation, which structures the new concepts in how businesses operate and interact with their stakeholders. Despite the rapid transformation, studies concerning the bibliometric review on IFR are still considered scarce in this so-called "digital era". Thus, the objective of this study is to perform bibliometric analysis on scientific literature published in the field of IFR, particularly from the years 1998 to 2020. The Scopus database was used to gather all the related literature on IFR. Apart from employing SPSS and Microsoft Excel software, we also utilize Publish or Perish software to integrate the data and perform simple analysis before using VOSviewer to perform data visualization. Publication growth, the productivity of research, and citation analysis were reported via standard bibliometric analysis. A total of 96 documents were retrieved based on the keyword search results. The study reveals that the vast majority of articles were written in English and published in journals and conferences. Most of these articles were in the business, management, and accounting fields. The findings of the study also point to future research, whereby the search query should be expanded to other accessible databases, including but not limited to the Web of Science, Google Scholar, and Dimensions, which would possibly contribute to more invaluable results.
\end{abstract}

Keywords: Internet Financial Reporting, Bibliometric Analysis

\section{Introduction}

As the global economy is undergoing a rapid digital transition, Internet Financial Reporting (IFR) has become the focal point for practitioners and researchers, structuring new principles on how companies function and communicate with their stakeholders (Ahmed, 2017; Cassar et al., 2019). The studies of Lymer et al (1999); Keliwon (2018) document that the application of IFR requires the use of technology, bolstered by internet-based communications and web resources, including multimedia, to disseminate financial reporting to investors, aiding them in their investment decision-making. Numerous studies have identified several advantages 
MANAGEMENT SCIENCES

Vol. 11, No. 3, 2021, E-ISSN: 2225-8329 @ 2021 HRMARS

that can be obtained via the use of IFR. For instance, the study by Xiao et al (2004) documents that IFR enables the dissemination of financial data along with corporate results via the corporate website, including non-financial information such as corporate governance (Kelton \& Young, 2008), social environment issues (Al-Arussi et al., 2009) to key stakeholders. Meanwhile, the study by Khan \& Ismail (2011) reveals that IFR plays an essential role in reaching out to global investors and, at the same time, fostering businesses' reputations.

Another critical factor that pushes for IFR adoption is that it can reduce data asymmetry and corporate debacles (Ndofor et al., 2015). Meanwhile, according to (Haistron \& Brooks, 2019), the employment of IFR also enhances the integrity of financial data, which is vital to maintaining market efficiency. The growing adoption of IFR to communicate with shareholders has also reduced printed-based financial reporting because IFR provides greater benefits to accommodate investors, especially in delivering real-time information (Almilia, 2009; Keliwon et al., 2018). On the other hand, there are also several drawbacks implicating the use of IFR. Accordingly, the main disadvantages are associated with the cost of retaining experts who are savvy in disseminating data via corporate websites, followed by infringement of data security by unauthorized personnel (Khan \& Ismail, 2011). Even so, IFR's involvement as a communication tool continues to grow under the vast range of benefits that can be explored in this so-called digital era for the industry and market (Cassar et al., 2019).

The study is thus aware of the extensive advancement of IFR in research and practice that had driven us to perform this bibliometric review. Therefore, we endeavor to examine IFR studies for the past 25 years and how this bibliometric analysis will shape future research. This bibliometric review addresses the following research questions:

1. What is the current trend in Internet financial reporting publications?

2. Which are the most influential articles on Internet financial reporting?

3. Which are the most popular themes of Internet financial reporting among scholars?

4. Who are the most influential authors of Internet financial reporting?

5. What is the current state of collaboration involving Internet financial reporting?

6. What is the intellectual structure of recent research on Internet financial reporting?

The organization of this study covers five main parts: Introduction, Literature Review, Data and Methods, Results and Discussion, and Conclusion and Limitation. The Results and Discussion part are supported using a comprehensive descriptive analysis through analysis of types of documents and sources, publication year, languages used in publications, sources of publication, geographical and institutional distribution, subject area and the trend in its fundamental intellectual structure. Lastly, we highlight the conclusions, limitations and suggest which areas future researchers should explore.

\section{Literature Review}

IFR is defined by Ashbaugh et al (1999) as internet technology to disseminate company financial information and performance. The central concept of IFR is financial reporting distribution, which is aided by internet-based communications and technology features such as online tools analysis and multimedia (Lymer et al., 1999; Lizzcharly et al., 2013). The description of IFR has been expanded to include the concept of complete disclosure of material information to assist shareholders in making better economic decisions (Ojah \& Mokoaleli-Mokoteli, 2012). Online technology has been increasingly popular as a means of commercial advertising and corporate reporting since the early 1990s, particularly in the years of globalization and digital business transition (Xiao et al., 2004). This has sparked numerous 
MANAGEMENT SCIENCES

Vol. 11, No. 3, 2021, E-ISSN: 2225-8329 @ 2021 HRMARS

studies on IFR among researchers. The vast majority of the early research was on the descriptive and exploratory nature of IFR, which focused on the existence of corporate websites facilitating the stock exchange globally (Khan \& Ismail, 2011).

From examining the existence of websites for businesses, the study then evolved more into researching the characteristics of financial data published on the corporate websites (Xiao et al., 2004; Kelton \& Yang, 2008; Ali Khan \& Ismail, 2011). This specifically emphasizes the key dimensions of IFR, which encompass content and presentation (Ali Khan \& Ismail, 2011), timeliness (Pirchergger \& Wagenhofer, 1999; Ezat \& El-Masry, 2008), usability, accessibility, navigation, and user support (Hanafi et al., 2009; Nel and Brummer, 2016). Most of the studies employed index-based measuring instruments, focusing on the existence of items on the annual reports (Kelton \& Yang, 2008; Hanafi et al., 2009, Almilia, 2015). On the other hand, several studies examine the qualitative characteristics of IFR to determine the usefulness of information (Dyezkowska, 2014; Amin \& Mohamed, 2016). There are also few studies engaging the use of a qualitative approach to determine the in-depth nature of IFR (Arafa, 2012; Ahmed et al., 2018). Nevertheless, the lack of rigorous regulations and specific standards that can address how and what information should be published on corporate websites remains unresolved (Sia et al., 2018).

The fact that IFR is still considered a voluntary reporting mechanism further exacerbates the issue (Leung et al., 2015; Amin \& Mohamed, 2016). As a result, these phenomena have resulted in variations in disclosure, making it more difficult for investors to make comparisons and leverage information (Efimova \& Rozhnova, 2018). It is also apparent that more studies have been conducted examining the extent of the impact of security risk on IFR in recent years (e.g., Fisher et al., 2004; Amin \& Mohamed, 2016; Efimova \& Rozhnova, 2018). This follows the prevalence of cyberattacks in several countries with large economies, such as China, Russia, Canada, and the United States (Cumming et al., 2017). Given the above discussions, continuous studies on IFR must be conducted to understand better how all issues relating to IFR are being addressed, especially in the era where advancements in technologies are rapidly affecting the manner and quality of corporate information being published (Tiberius \& Hirth, 2019). As such, this bibliometric review study can serve as the platform that summarizes the literature of IFR over the years, including identifying a potential avenue for future research.

\section{Methods}

Bibliometric analysis is gaining popularity as one of the approaches used to expose the research pattern (Ahmi \& Mohammad, 2019). It has been widely used in the management field in recent years (Ferreira et al., 2014). It is used as an alternative to conventional literature review. Bibliometrics consists of a quantitative study of physical published units, bibliographic units, or the surrogates for both (Broadus, 1987). In addition, a methodological approach in the execution of a bibliometric analysis might discover more comprehensive details related to the publications, including authors, keyword frequency and citations (Rusly et al., 2019). The bibliometric analysis could provide descriptive patterns of publications based on a domain, area, country, and period. In bibliographic research, diverse metrics will be used, such as publishing outlet, type of publication, authorship, affiliations, country, h-index, and gindex, which were among the most commonly examined aspects (Ahmi \& Mohammad, 2019). 


\section{MANAGEMENT SCIENCES}

Vol. 11, No. 3, 2021, E-ISSN: 2225-8329 @ 2021 HRMARS

Scopus is the most comprehensive searchable citation and abstract searchable literature source (Chadegani, 2013) and the largest archive of scholarly works (Burnham, 2006). This database was used as the platform for extracting previous web accessibility work. The database provides details of the publication, including the type of access, year, author name, area topic, type of text, source's title, keyword, affiliation, country, source, and language.

We narrowed the search of web accessibility studies based on titles to specify further critical academic works on the research domain examined. Due to the large number of studies on financial reporting, this review concentrated only on documents relevant to IFR based on the title of the articles (Shafiy \& Kamalluarifin, 2016). As such, the following questionnaire was carried out: TITLE-ABS-KEY ("Internet financial reporting," "e-Financial reporting," "Electronic financial reporting," or "Online financial reporting")
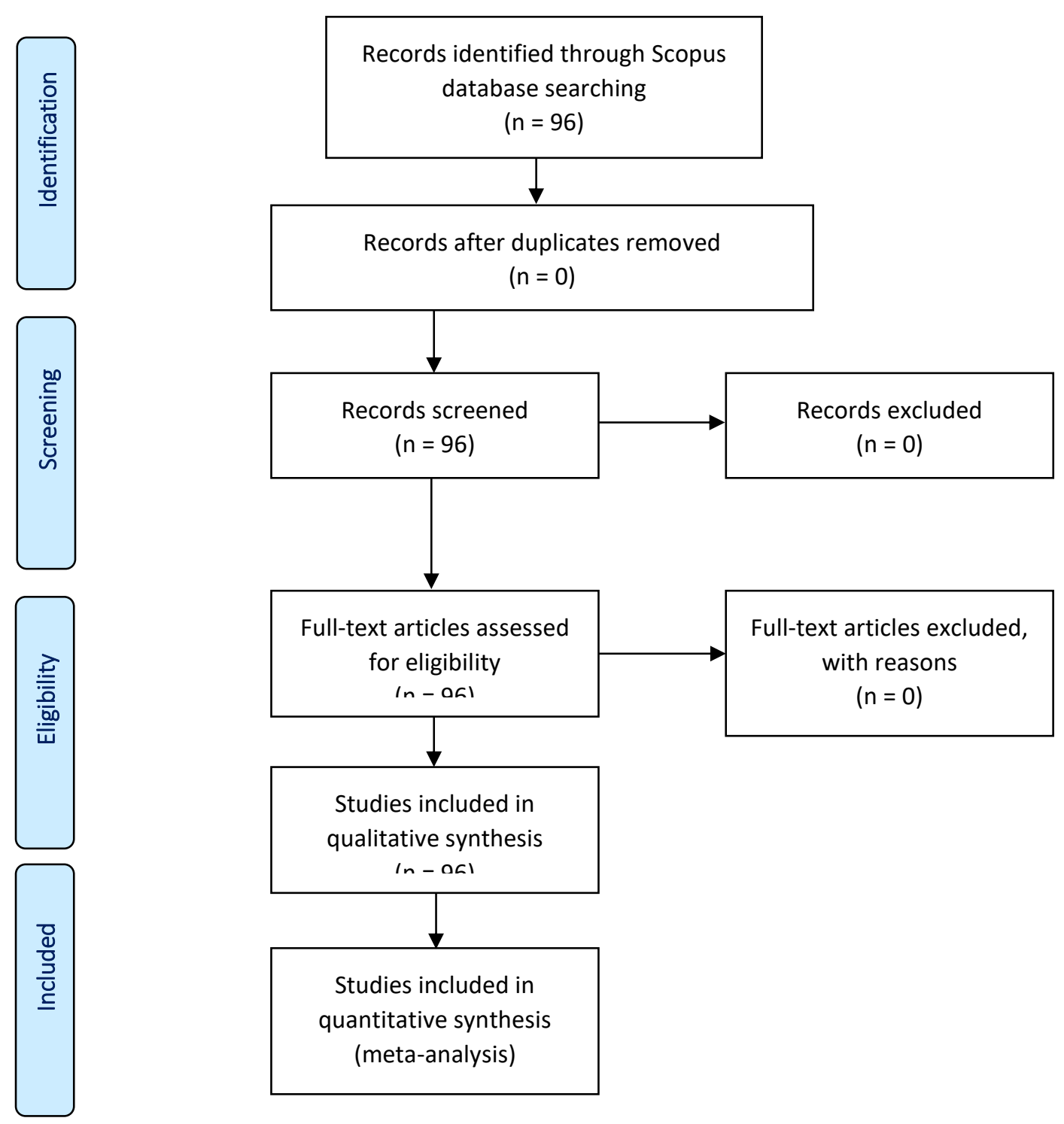

Figure 1. PRISMA Flow Diagram

Source: Moher, Liberati, Tetzlaff, Altman, The PRISMA Group (2009) 
MANAGEMENT SCIENCES

Vol. 11, No. 3, 2021, E-ISSN: 2225-8329 @ 2021 HRMARS

\section{Results}

The analysis of the extracted scholarly works covers document types and source types, annual growth, document language, subject area, analysis of keywords, the productivity of the country, analysis of authorship and citation. The bulk of the results are interpreted in terms of frequency and percentage. Meanwhile, as some retrieved documents per year, we present the annual growth data, including their frequency, percentage, and cumulative percentage until November 2020. We publish citation analysis and reveal 20 of the most cited papers in web accessibility as citation metrics.

Evolution of Publication

As indicated in Figure 1, the first research on IFR was published in 1998 by Amernic (1998) with their paper titled, "Close Readings" of Internet Corporate Financial Reporting: Towards a More Critical Pedagogy on the Information Highway". The growth of the related publications has then risen gradually, especially after 2008. Then, the development of associated publications gradually increased, especially after 2008. As for 2020 , several publications have already been scheduled and indexed in the Scopus database even though the year is still running.

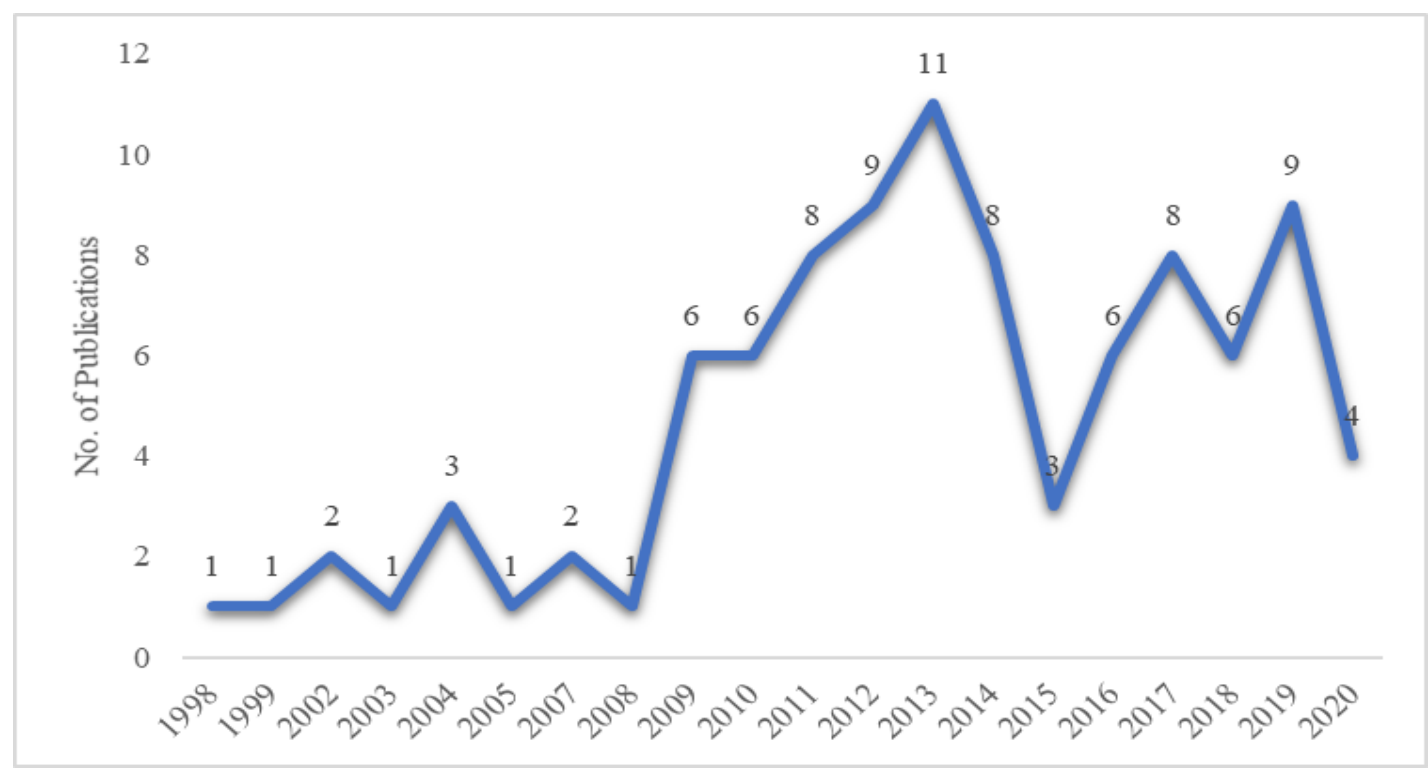

Fig. 1: Internet Financial Reporting publications, 1998-2020 ( $n=96)$

\section{Document and Source Types}

This study found 13 types of published documents related to IFR, namely articles, conference papers, book chapters, conferences, reviews and retracted. As exhibited in Table 1, most publications were articles, which account for $80.2 \%$, followed by conference papers, $12.5 \%$. Collectively, the other documents made up about 7.2\%, with each type being less than $3.5 \%$ of the total documents. Furthermore, four source types are also presented in Table 1. Journals $(80.2 \%)$ are the highest category, followed by conference proceedings with $14.6 \%$. The number of documents accounted for $3.1 \%$ and $2.1 \%$, respectively, representing book series and books. 
Table 1: Document and Source Types

\begin{tabular}{|c|c|c|c|c|c|}
\hline Document Type & $\begin{array}{c}\text { Total } \\
\text { Publications } \\
\text { (TP) }\end{array}$ & $\begin{array}{r}\text { Percentag } \\
\text { e (\%) } \\
\end{array}$ & Source Type & $\begin{array}{c}\text { Total } \\
\text { Publications } \\
\text { (TP) } \\
\end{array}$ & $\begin{array}{r}\text { Percenta } \\
\text { ge (\%) }\end{array}$ \\
\hline Article & 77 & 80.2 & Journals & 77 & 80.2 \\
\hline Conference & 12 & 12.5 & & 14 & 14.6 \\
\hline Paper Book & 3 & 3.1 & Conference & 3 & 3.1 \\
\hline Chapter & & & Book Series & & \\
\hline Conference & 2 & 2.1 & & 2 & 2.1 \\
\hline Review & & & Books & & \\
\hline Review & 1 & 1.0 & & & \\
\hline Retracted & 1 & 1.0 & & & \\
\hline Total & 96 & 100.00 & Total & 96 & 100.00 \\
\hline
\end{tabular}

\section{Languages of Documents}

Since English is the universally recognized literary language, almost all papers are written in English. Table 2 reveals that most of the documents obtained were published in English (99.0\%). However, one published article was released in dual languages, written in English and German (1).

Table 2: Languages

\begin{tabular}{lcr}
\hline & \multicolumn{2}{c}{ Total Publications } \\
Language & (TP)* & Percentage (\%) \\
\hline English & 96 & 99.0 \\
German & 1 & 1.0 \\
\hline Total & 97 & $\mathbf{1 0 0 . 0 0}$ \\
\hline *One document has been prepared in dual languages
\end{tabular}

\section{Subject Area}

*One document has been prepared in dual languages

The written documents were also submitted by this study based on its subject areas. Much of the Internet Financial Reporting studies were in Business, Management, and Accounting, representing $37.6 \%$ of the total reports, followed by Economics, Econometrics and Finance (15.2\%), Computer Science (11.2\%), and Social Sciences (11.2\%). Table 3 includes the other subject areas covered in the research on Internet Financial Reporting. 
Table 3: Subject Area

\begin{tabular}{lcc}
\hline Subject Area & Total Publications (TP) & Percentage (\%) \\
\hline Business, Management and Accounting & 67 & 37.6 \\
Economics, Econometrics and Finance & 27 & 15.2 \\
Computer Science & 20 & 11.2 \\
Social Sciences & 20 & 11.2 \\
Decision Sciences & 18 & 10.1 \\
Arts and Humanities & 7 & 3.9 \\
Engineering & 6 & 3.4 \\
Multidisciplinary & 4 & 2.2 \\
Mathematics & 2 & 1.1 \\
Biochemistry, Genetics and Molecular & 1 & 0.6 \\
Biology & & \\
Energy & 1 & 0.6 \\
Environmental Science & 1 & 0.6 \\
Materials Science & 1 & 0.6 \\
Neuroscience & 1 & 0.6 \\
Physics and Astronomy & 1 & 0.6 \\
Psychology & 1 & 0.6 \\
\hline
\end{tabular}

\section{Geographic Distribution of Publication and Affiliation}

Researchers from 126 separate countries contributed to the release of the retrieved documents. Table 4 lists the top 12 countries subscribing to Internet Financial Reporting publications. With a total of 15 records, Indonesia was first, followed by Malaysia (14), the United States (13) and China (7). The United States (U.S.) was ranked first with 952 citations regarding the number of comprehensive sources by region, followed by New Zealand (380).

Table 4: Top 12 Countries Contributed to the Publications

\begin{tabular}{lccccccc}
\hline \multicolumn{1}{c}{ Country } & $\begin{array}{c}\text { Total } \\
\text { Publications }\end{array}$ & NCP & $\begin{array}{c}\text { Total } \\
\text { Citations }\end{array}$ & CP & C/CP & h & $\mathbf{g}$ \\
\hline 1 Indonesia & 15 & 6 & 66 & 4.4 & 11.0 & 3 & 6 \\
2 Malaysia & 14 & 7 & 19 & 1.4 & 2.7 & 2 & 4 \\
3 United States & 13 & 12 & 952 & 73.2 & 79.3 & 9 & 12 \\
4 China & 7 & 1 & 14 & 2.0 & 14.0 & 1 & 1 \\
5 Egypt & 6 & 5 & 42 & 7.0 & 8.4 & 4 & 5 \\
6 New Zealand & 6 & 6 & 380 & 63.3 & 63.3 & 5 & 6 \\
7 Australia & 5 & 3 & 42 & 8.4 & 14.0 & 3 & 3 \\
8 Spain & 5 & 4 & 200 & 40.0 & 50.0 & 4 & 4 \\
9 United Arab Emirates & 5 & 5 & 48 & 9.6 & 9.6 & 4 & 5 \\
10 United Kingdom & 5 & 4 & 59 & 11.8 & 14.8 & 4 & 4 \\
11 Canada & 4 & 4 & 51 & 12.8 & 12.8 & 4 & 4 \\
12 Oman & 4 & 4 & 340 & 85.0 & 85.0 & 4 & 4 \\
\hline
\end{tabular}

Notes: TP=Total number of publications; NCP=Number of Cited Publications; TC=Total Citations; $C / P=A v e r a g e$ Citations per Publication; $C / C P=A v e r a g e$ Citations per Cited Publication; $\mathrm{h}=\mathrm{h}$-index; and $\mathrm{g}=\mathrm{g}$-index 


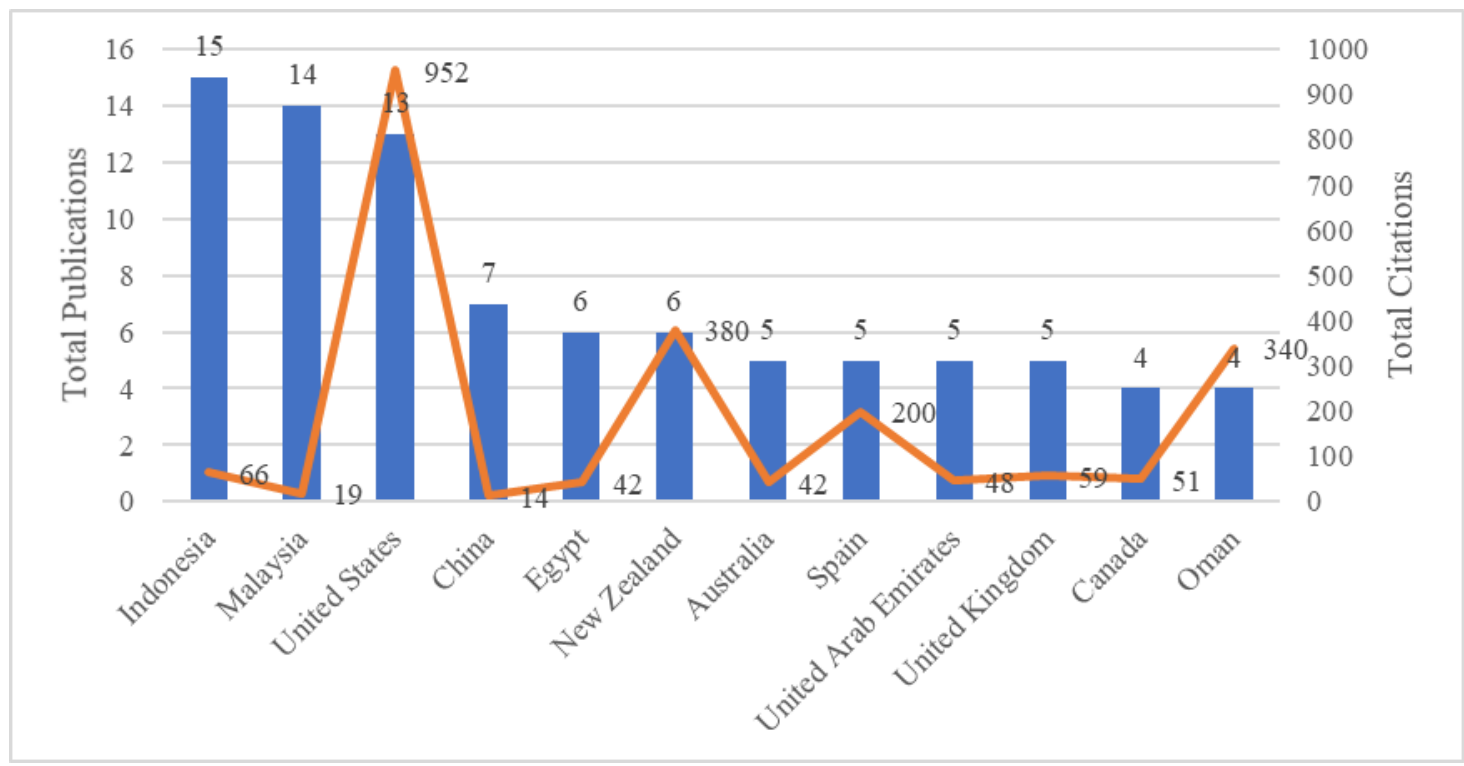

Figure 2: Total Publications and Citations by Countries

\section{Authorship Analysis}

The most involved authors in the publication of IFR documents are also examined in this research. The most active writers with a minimum of three publications have been mentioned in Table 5. Based on the table, the top authors on IFR topics include Oyelere, Ismail, Khan, Mohamed, Almilia. Furthermore, Table 5 also shows the number of times other scholars have cited papers on IFR, as stated in the Scopus database. Oyelere has published six publications, making him the top author in the field, with 381 total citations.

Table 5: Top 5 Productive Authors

\begin{tabular}{lccccccc}
\hline \multicolumn{1}{c}{ Country } & $\begin{array}{c}\text { Total } \\
\text { Publications }\end{array}$ & NCP & $\begin{array}{c}\text { Total } \\
\text { Citations }\end{array}$ & CP & C/CP & h & g \\
\hline 1 Oyelere, P. & 6 & 6 & 381 & 63.5 & 63.5 & 5 & 6 \\
2 Ismail, N.A. & 4 & 2 & 3 & 0.8 & 1.5 & 1 & 1 \\
3 Khan, M.N.A.A. & 6 & 3 & 7 & 1.2 & 2.3 & 2 & 2 \\
4 Mohamed, E.K.A. & 4 & 4 & 39 & 9.8 & 9.8 & 3 & 4 \\
5 Almilia, L.S. & 3 & 2 & 9 & 3.0 & 4.5 & 2 & 3 \\
\hline
\end{tabular}

Notes: TP=Total number of publications; $\mathrm{NCP}=$ Number of Cited Publications; $\mathrm{TC}=$ Total

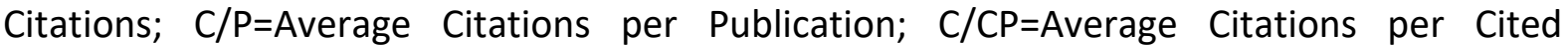
Publication; $h=h$-index; and $g=g$-index

\section{Citation Analysis}

To obtain the citation metrics for the retrieved data, we used Harzing's Publish or Perish software. To produce the citation metrics, data gathered from the Scopus database was imported into this software. As of November 11, 2020, Table 6 summarises the citation metrics for the documents obtained. The total number of citations per year, citations per article, and citations per author are included in the summary. 
Table 6: Citations Metrics

\begin{tabular}{ll}
\hline Metrics & Data \\
\hline Publication years & $1998-2020$ \\
Citation years & $22(1998-2020)$ \\
Papers & 96 \\
Citations & 1891 \\
Citations/year & 85.95 \\
Citations/paper & 19.70 \\
Citations/author & 9.32 \\
Papers/author & 0.47 \\
Authors/paper & 2.47 \\
h-index & 16 \\
g-index & 42 \\
\hline
\end{tabular}

\section{Keywords Analysis}

The authors' keywords were mapped with VOSviewer, a software tool for creating and visualizing bibliometric networks. Figure 3 displays a network visualization of the authors' keywords, using color, circle size, font size, and connecting line thickness to indicate the keyword relationships. Keywords of the same color, for instance, were often listed together. Thus, Internet Financial Reporting, Voluntary Disclosure, and IFR shared a standard color (green) in this review, for example, indicating that these keywords are closely related and typically co-occurred.

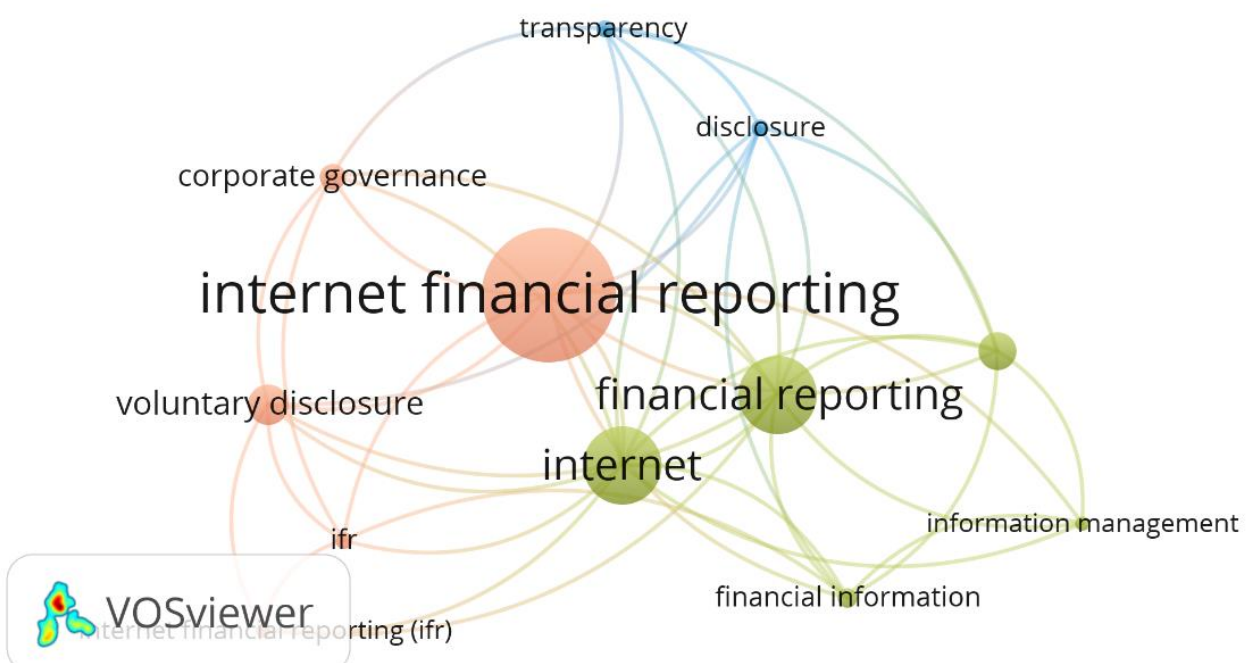

Figure 3: Network visualisation map of the author keywords

Meanwhile, after eliminating the core keywords listed in the search question, Internet Financial Reporting, Financial Reporting, Internet, Voluntary Disclosure, and Finance are among the highest occurrences. Table 7 displays the top 20 keywords used in the study of Internet Financial Reporting. 
Table 7: Top Keywords

\begin{tabular}{ccc}
\hline Rank & Keyword & Frequency \\
\hline 1 & Internet Financial Reporting & 46 \\
2 & Financial Reporting & 27 \\
3 & Internet & 27 \\
4 & Voluntary Disclosure & 14 \\
5 & Finance & 13 \\
6 & Corporate Governance & 9 \\
7 & Financial Information & 7 \\
8 & Disclosure & 6 \\
9 & IFR & 6 \\
10 & Transparency & 6 \\
11 & Information Management & 5 \\
12 & Internet Financial Reporting (IFR) & 4 \\
13 & Internet Reporting & 4 \\
14 & Financial Disclosure & 3 \\
15 & Online Reporting & 3 \\
16 & Auditing & 2 \\
17 & Auditors & 2 \\
18 & Financial Reports & 2 \\
19 & Disclosure Transparency & 1 \\
20 & Electronic Financial Reporting & 1 \\
\hline
\end{tabular}

\section{Discussion}

There has been a gradual increase since 2008 in the number of linked articles. Studies on IFR have discovered 13 different forms of publications, such as journal articles and conference papers and book chapters and conference reviews and retracted documents. Articles accounted for $80.2 \%$ of all publications, with conference papers accounting for $12.5 \%$ of all publications. Other sorts of documents accounted for around $7.2 \%$ of total documents, with each type accounting for less than 3.5\%. There were four different categories of sources. Journals account for $80.2 \%$ of all publications, with conference proceedings accounting for $14.6 \%$ of all publications. Book series and individual books made for $3.1 \%$ and $2.1 \%$ of the total number of documents.

Almost all papers are written in English because it is the most widely accepted literary language. However, one article was issued in English and German and was authored in both languages (1). This study also provided written documentation based on the study's subject areas. Business, Management, and Accounting accounted for $37.6 \%$ of the total reports, followed by Economics, Econometrics, and Finance (15.2\%), Computer Science, and Social Sciences (11.2\% respectively).

Researchers from 126 different nations helped to release the collected documents. Indonesia led the way with 15 records, followed by Malaysia (14), the United States (13) and China (7). The United States (U.S.) placed first overall in citations by region, with 952 citations, followed by New Zealand with 380. This research also examines the most active authors in the publication of Internet Financial Reporting topics. The most prolific writers, having at least three publications. Oyelere, Ismail, Khan, Mohamed, and Almilia are among the top authors on Internet Financial Reporting issues. Meanwhile, after excluding the search query's main 
MANAGEMENT SCIENCES

Vol. 11 , No. 3, 2021, E-ISSN: 2225-8329 @ 2021 HRMARS

terms, Internet Financial Reporting, Financial Reporting, Internet, Voluntary Disclosure, and Finance rank among the most often occurring keywords.

\section{Conclusion}

This study only evaluates the list of literature that, as indicated by the article's title, focuses on the impact of the IFR. Based on the findings of this study, it was revealed that journal articles were the highest form of publication. Most of these articles were in the business, management, and accounting fields, which are mostly written in English. The findings of the study also indicate that numerous studies on the effect of adoption on IFR have favored voluntary adoption over compulsory adoption. Additionally, researchers discovered that adopting IFR can improve the dissemination of financial data (Xiao et al., 2004) and corporate results to key stakeholders via the corporate website.

Meanwhile, according to Khan \& Ismail (2011), IFR is vital in attracting global investors while enhancing companies' reputations. Another reason for IFR adoption is its capacity to eliminate data asymmetry and company debacles (Ndofor et al., 2015). Using IFR also improves the integrity of financial data, which is critical for market efficiency (Haistron \& Brooks, 2019). The increased usage of IFR to communicate with shareholders has reduced printed-based financial reporting since IFR attracts more potential investors (Almilia, 2009; Keliwon et al., 2018).

Nevertheless, the study also reveals that IFR is still not widely known or used. Public agencies, local governments, professional organizations, and educational institutions can all help educate the public on the benefits of IFR adoption. More research is needed to determine the causes of low adoption rates. The data demonstrates that a study on the impact of IFR has not improved significantly since 2013. It can be observed that IFR focuses on the influence of investors, accounting, and finance. Overall, IFR research seems promising. There is always room to improve IFR studies. Although researchers face hiccups and difficulties, such as data availability and IFR awareness, a collaborative effort from government, academics, and practitioners could help overcome these in the future. It is anticipated that it will be able to identify potential research gaps on the relevant topic of IFR as explicated in the following section.

\section{Limitation and Study Forward}

There are a few drawbacks to our analysis that are intrinsic to the database used. Thus, while Scopus is one of the largest databases, it should be emphasized that there are still unindexed journals, and therefore, publications in these journals may have been neglected. In addition, this research concentrated only on IFR based on the title of the documents. Therefore, other literature relating to IFR was also disregarded, but the word in the title was not explicitly used. It is also important to highlight that there can be no $100 \%$ perfect search question, falsepositive and false-negative results. Based on the discussions above, the search query should be expanded to other accessible databases in future studies, e.g., Web of Science, Google Scholar, and Dimensions. Combining all databases would possibly contribute to more exciting and invaluable results. Furthermore, given that the dimension of IFR is considered broad yet voluntary in nature, it would be worth to research on the quality of IFR as it can have impact on the investors' investment decision making. This entails the type of methods used to assess its quality. Finally, given the fact that IFR is vulnerable to cyberattack especially in this socalled "digital era", this points to the need to conduct research on how corporations could 
MANAGEMENT SCIENCES

Vol. 11, No. 3, 2021, E-ISSN: 2225-8329 @ 2021 HRMARS

keep the issue at bay. Hence, realizing the importance of having a profound understanding on IFR would encourage and enable regulatory bodies as well as the accounting professional bodies to implement accounting reforms that not only improve IFR quality but also address other critical concerns like IFR governance.

\section{References}

Chadegani, A., Salehi, H., Yunus, M., Farhadi, H., Fooladi, M., Farhadi, M., \& Ale Ebrahim, N. (2013). A comparison between two main academic literature collections: Web of Science and Scopus databases. Asian social science, 9(5), 18-26.

Ahmed, A. H., Burton, B. M., \& Dunne, T. M. (2017). The determinants of corporate internet reporting in Egypt: an exploratory analysis. Journal of Accounting in Emerging Economies, 7(1), 35-60.

Ahmed, A. H., Mardini, G. H., Burton, B. M., \& Dunne, T. M. (2018) 'Is internet reporting useful? Evidence from Egypt', Journal of Applied Accounting Research, Vol. 19, No. 4, pp.574-591.

Ahmi, A., \& Mohamad, R. (2019). Bibliometric Analysis of Global Scientific Literature on Web Accessibility. International Journal of Recent Technology and Engineering, 7(6), 250258.

Ahmi, A., \& Nasir, M. H. (2019). Examining the Trend of the Research on eXtensible Business Reporting Language (XBRL): A Bibliometric Review. International Journal of Innovation, Creativity and Change, 5(2), 1145-1167.

Almilia, L. S. (2009). Determining Factors of Internet Financial Reporting in Indonesia, Accounting and Taxation. 1(1), 87-99.

Al-Arussi, A. S., Selamat, M. S., \& Hanefah, M. M. (2009). Determinants of financial and environmental disclosures through the internet by Malaysian companies. Asian Review of Accounting, 17(1), 59-76.

Ali Khan, M. N. A., \& Ismail, A. N. (2011a). The Level of Internet Financial Reporting of Malaysian Companies, Asian Journal of Accounting and Governance, 2, 27-39.

Amin, H. M. G., \& Mohamed, E. K. A. (2016). Auditors' perceptions of the impact of continuous auditing on the quality of Internet reported financial information in Egypt, Managerial Auditing Journal, 31(1), 111-132.

Arafa, I. (2012) Evaluating the Impact of Institutional Logic on the Corporate Internet Reporting by Egyptian Listed Companies, Doctoral dissertation, Aston University.

Amernic, J. H. (1998). 'Close readings' of internet corporate financial reporting: towards a more critical pedagogy on the information highway. The Internet and Higher Education, 1(2), 87-112.

Ashbaugh, H., Johnstone, K. M., \& Warfield, T. D. (1999). Corporate reporting on the internet, Accounting Horizons, 13(3), 241-257.

Broadus, R. N. (1987). Toward a definition of "bibliometrics". Scientometrics, 12(5-6), 373379.

Burnham, J. F. (2006). Scopus database: a review. Biomedical digital libraries, 3(1), 1-8.

Cassar, C., Heath, D., \& Micallef, L. (2019). What is the digital economy? Unicorn, transformation and internet of things. Mriehel, Malta. Retrieved from https://www2.deloitte.com/mt/en/profiles/dheath.html

Cumming, D., Johan, S., \& Schweizer, D. (2017). Information systems, agency problems, and fraud. Information Systems Frontiers, 19(3), 421-424. 
MANAGEMENT SCIENCES

Vol. 11, No. 3, 2021, E-ISSN: 2225-8329 ๔ 2021 HRMARS

Dyczkowska, J. (2014). Assessment of quality of internet financial disclosures using a scoring system. A case of Polish stock issuers, Accounting and Management Information Systems, 13(1), 50-81.

Efimova, O., \& Rozhnova, O. (2018). The corporate reporting development in the digital economy. In The 2018 International Conference on Digital Science, Springer Cham, 7180.

Ezat, A., \& El-Masry, A. (2008). The impact of corporate governance on the timeliness of corporate internet reporting by Egyptian listed companies. Managerial finance, 34(12), 848-867.

Ferreira, M. P., Li, D., Reis, N. R., \& Serra, F. R. (2014). Culture in international business research: A bibliometric study in four top I.B. journals. Management Research: The Journal of the Iberoamerican Academy of Management, 12(1), 68-91.

Fisher, R., Oyelere, P., \& Laswad, F. (2004). Corporate reporting on the Internet: Audit issues and content analysis of practices, Managerial Auditing Journal, 19(3), 412-440.

Hairston, S. A., \& Brooks, M. R. (2019). Derivative accounting and financial reporting quality: A review of the literature. Advances in accounting, 44(1), 81-94.

Hanafi, S. R., Kasim, M. A., Ibrahim, M. K., \& Hancock, D. R. (2009). Business Reporting on the Internet: Development of a Disclosure Quality Index, International Journal of Business and Economics, 8(1), 55-79.

Keliwon, K. B., Shukor, Z. A., \& Hassan, M. S. (2018). Internet financial reporting (IFR) disclosure position and firm value. Asian Journal of Accounting and Governance, 9(1), 111-122.

Leung, S., Parker, L., \& Courtis, J. (2015). Impression management through minimal narrative disclosure in annual reports, British Accounting Review, 47(3), 275-289.

Lizzcharly, P., Medyawati, H., Silfianti, W., \& Hermana, B. (2013). Internet Financial Reporting Index Analysis: An Overview from the State Owned Enterprise in Indonesia. Journal of Economics, Business and Management, 1(3), 281-284.

Lymer A., Debreceny, R., Gray, G., \& Rahman, A. (1999). Business Reporting on the Internet. London: International Accounting Standard Committee.

Kelton, A. S., \& Yang, Y. (2008). The impact of corporate governance on Internet financial reporting, Journal of Accounting and Public Policy, 27, 62-87.

Ndofor, H. A., Wesley, C., \& Priem, R. L. (2015). Providing CEOs With Opportunities to Cheat: The Effects of Complexity-Based Information Asymmetries on Financial Reporting Fraud, Journal of Management, 41(6), 1774-1797.

Nel, G. F., \& Brummer, L. M. (2016). The development of a measurement instrument to measure the quality of internet investor relations. South African Journal of Business Management, 47(4), 15-25.

Ojah, K., \& Mokoaleli-Mokoteli, T. (2012). Internet financial reporting, infrastructures and corporate governance: An international analysis. Review of Development Finance, 2(2), 69-83.

Rusly, F. H., Ahmi, A., Yakimin, Y., Talib, A., \& Rosli, K. (2019). Global perspective on payroll system patent and research: A bibliometric performance. International Journal of Recent Technology and Engineering, 8(2S2), 148-157.

Shafiy, W. F., \& Kamalluarifin, W. (2016). The influence of corporate governance and firm characteristics on the timeliness of corporate internet reporting by top 95 companies in Malaysia. Procedia Economics and Finance, 35,156-165. 
Sia, C. J., Brahmana, R., \& Memarista, G. (2018). Corporate Internet Reporting and Firm Performance: Evidence from Malaysia. Contemporary Economics, 12(2), 153-164.

Tiberius, V., \& Hirth, S. (2019). Impacts of Digitization on Auditing: A Delphi Study for Germany. Journal of International Accounting, Auditing and Taxation, 37, 100288

Xiao, J. Z., Yang, H., \& Chow, C. W. (2004). The determinants and characteristics of voluntary Internet-based disclosures by listed Chinese companies, Journal of Accounting and Public Policy, 23(3), 191-225. 